\author{
Abstracta Iranica \\ Abstracta Iranica Revue bibliographique pour le domaine irano-aryen \\ Volume 37-38-39 | 2018 \\ Comptes rendus des publications de 2014-2016
}

\title{
Desmond Durkin-Meisterernst. Grammatik des Westmitteliranischen (Parthisch und Mittelpersisch)
}

\section{Thomas Jügel}

\section{(2) OpenEdition \\ 12 Journals}

Electronic version

URL: http://journals.openedition.org/abstractairanica/43057

DOI: $10.4000 /$ abstractairanica.43057

ISBN: 1961-960X

ISSN: 1961-960X

Publisher:

CNRS (UMR 7528 Mondes iraniens et indiens), Éditions de l'IFRI

Electronic reference

Thomas Jügel, « Desmond Durkin-Meisterernst. Grammatik des Westmitteliranischen (Parthisch und Mittelpersisch) », Abstracta Iranica [Online], Volume 37-38-39 | 2018, document 13, Online since 30 December 2018, connection on 27 September 2020. URL : http://journals.openedition.org/ abstractairanica/43057 ; DOI : https://doi.org/10.4000/abstractairanica.43057

This text was automatically generated on 27 September 2020

Tous droits réservés 


\title{
Desmond Durkin-Meisterernst. Grammatik des Westmitteliranischen (Parthisch und Mittelpersisch)
}

\author{
Thomas Jügel
}

\section{REFERENCES}

Desmond Durkin-Meisterernst. Grammatik des Westmitteliranischen (Parthisch und Mittelpersisch). (Sitzungsberichte der phil.-hist. Klasse 850, Veröffentlichungen zur Iranistik 73, Grammatica Iranica, Band 1), Vienna: Verlag der Österreichischen Akademie der Wissenschaften, 2014, 602 p. Print Edition: ISBN 978-3-7001-7556-8, Online Edition: ISBN 978-3-7001-7605-3.

1 The present Grammar of West Middle Iranian (i.e. Middle Persian and Parthian) by Durkin-Meisterernst is designed to meet a desideratum which has been long and much felt in Iranian studies. On 602 pages, Durkin-Meisterernst gives a detailed survey of West Middle Iranian corpora ( $25 \mathrm{pp}$.), secondary sources $(3 \mathrm{pp}$.$) , writing systems and$ palaeography (55 pp.), sound systems and sound changes (64 pp.), word formation (49 pp.), and a description of word classes, their categories and historical derivation (64 pp.), of formation and usage of grammatical categories (143 pp.), and of syntax sensu stricto (53 pp.). The appendix contains chapters about verbs of the mixed Parthian and Persian text Draxt asūrig, and the attestations of numerals. The index of quoted material facilitates the usage of this book, and the bibliography is a helpful guide on its own. Due to its clear structure, it should also be easy to handle for non-native speakers of German.

2 Being based on a large body of material throughout, Durkin-Meisterernst's descriptive approach yields a rich amount of reliable data, which is neatly arranged. The transliteration of examples is given in the appendix together with their sigla. DurkinMeisterernst offers a broad classification by specifying the examples as Manichaean 
(MpT/PaT), Zoroastrian (MpB/PaB), and inscriptional corpora (MpI/PaI). DM's focus on Manichaean texts is well justified due to the much clearer data.

3 Although Parthian and Persian are quite close in many respects, Durkin-Meisterernst keeps them conscientiously apart. His fine-grained analyses of the semantic differences make this grammar a most useful handbook for editors-to-be.

4 The chapter on the phonological system shows a solid etymological background. Especially, the presentation of inherited differences and common features and of new inventions is very helpful.

5 This marvellous study is a model of accuracy. Its detailedness (more than 1000 examples!) forms a solid and inspiring base for future investigations. It is a treasure of information diligently compiled and nicely arranged by a true expert of Middle Iranian philology.

6 My detailed review was published 2014 in BSOAS 77/3, pp. 598-600.

\section{AUTHORS}

THOMAS JÜGEL

Mondes iranien et indien 